\title{
An Empirical Testing of the Theory of Downgrading in Cameroon
}

\author{
Etgard MANGA ENGAMA \\ Lecturer-Researcher \\ Advanced School of Economics and Commerce (ESSEC) \\ University of Douala - Cameroon
}

\begin{abstract}
:
Despite the downgrading of educational systems in Africa and Cameroon in particular, population growth leads to a significant number of graduates which is more than the absorption capacity of the job market. Competition between job candidates leads to over-education. Using an endogenous model of wage determination, we find that the increasing number of graduates accept lower wages showing that the signalling role of certificates is reduced with the increasing number of graduates.
\end{abstract}

Key words: over-education, certificate, downgrading, wages

\section{Introduction}

There has been a sustained growth in the number of registered students for several years in Cameroon. This growth is by the compulsory schooling policy and the increase in the number of schools and universities. In fact, each year, in addition to the newly created schools, secondary schools are transformed into high-schools and in 1993, the ministry of higher education witnessed the number of universities increase from one to six state universities ${ }^{1}$, in addition to the number of higher institutes of technologies. Moreover, the high demand led to a liberalisation of professional training to the point that each year, the number of private institutions grows significantly with a high enrolment. One of these universities is the Catholic University of Central Africa established in 1991.

The logical consequence of this growth in school enrolment is an increase in the number of graduates. Consequently, educational policies aimed at continuously increasing the level of education can logically be the subject of interrogations (Guironnet, 2005; Duru-Bellat, 2006; Caliendo and Schmidl, 2016). If Cameroonians continue to invest in education, it is certainly because it is profitable. However, the bad economic situation reveals an imbalance between the supply and demand of graduates resulting in an excess of graduates relative to the capacity of absorption of the job market. While supposing following Gamel (2000) that the contents of trainings and the level of certificates do not change with time: which amounts to postulating the absence of a qualitative "devaluation" of certificates ${ }^{2}$, we highlight the quantitative "dimension" of the phenomenon of downgrading. Following this reasoning, the difficulty of finding a job increases competition between jobseekers and favours over-education. Consequently, as Vinokur (1995) highlights it, the graduate does not behave more as a small capitalist who seeks to rationally manage his resources, but as a sportsman who aims at the podium.

Competition between graduates implies increasingly longer studies and consequently leads to the phenomenon of overeducation to the point that the abilities necessary for the current job are lower than those certified by the diploma obtained (Manga Engama, 2007; Aliaga and Lê, 2016; Boisson-Cohen, Garner and Zamora, 2017). The graduates thus encounter more and more difficulties to obtain a job corresponding to their real level of education. The main objective of this study is to analyse the phenomenon of over-education of the graduates of secondary and higher education. It is structured in four sections. The first examines the theoretical framework of over-education.

The second section presents the data and some descriptive statistics. The third section presents the econometric model used and the fourth section presents and discusses the results.

\footnotetext{
${ }^{1}$ Cameroon went from a single university (university of Yaoundé) to six state universities: university of Buea, Douala, Dschang, Ngaoundéré, Yaoundé I and Yaoundé II.

${ }^{2}$ The qualitative degradation of certificates refers to the educational system and can be reflected by a fall in standards while a quantitative degradation is reflected by an excessive issuing of certificates relative to the absorption abilities of the job market.
} 


\section{1- Over-education and downgrading of certificates: theoretical Framework}

\section{1- Theoretical framework of over-education}

Traditionally, economists focus on the professional advantages related to the job to which the education prepares or eases access to. In the sixties, Becker, Mincer and Schultz developed the theory of the human capital according to which individuals engage themselves to many activities whose goals are not immediate pleasure, but future financial and non-financial benefits. Education thus appears as an investment whose returns cannot be evaluated without reference to the job market. Also, beyond the policy of compulsory schooling, the demand for education varies with its expected returns which in turn depend on the conditions of supply and demand for labour.

The literature on over-education ("surplus schooling" or supplementary education) relates to a required schooling that is generally measured in three different ways in the literature on over-education ${ }^{3}$ :

- analysis of the job (JA - job analysis) carried out by a specialist; the most common example being the DOT (dictionary of occupational titles);

- the self-assessment of the worker (WA - worker self-assessment) through which the worker specifies the education necessary to perform the function;

- the realised matches ( $R M$ - realised matches) in which the necessary education is established going from the levels generally reached by the workers occupying the functions concerned.

Duncan and Hoffman (1981) make a distinction between the level of education reached by a worker and the training required by the function that he occupies, thus bringing out a means of measuring not only over-education, but also under-education. They then evaluate the benefits of these years of difference from the necessary years of education.

One of the pioneers of research on the phenomenon of over-education is Freeman (1976) who for the United States finds that the level of benefit for one level of diploma had significantly decreased. This fall is according to him due to an excess supply of graduates. This calls into question the idea according to which: a diploma represents a profitable investment and a virtual guarantee of economic success. This study is to date an important focus of the literature on the phenomenon of downgrading of graduates.

According to the theory of human capital, training constitutes a suitable investment for increasing the productivity of an individual and consequently improves his qualification and remuneration. For Mincer (1974), the level of education is only one of the components among others (such as professional experience, know-how, ...). Supposing that the job market is fully efficient, companies who seek to maximise their profits must use the competences of employees efficiently. The competences of the employees will thus be adapted to the profile of the job to the point of not witnessing any situations of downgrading. However, the theory of the human capital considers the existence of periods during which individuals or the society invests in education beyond the requirements in graduate labour. According to Freeman (1976), such an imbalance is supposed to be temporary and re-absorbed naturally by the reactions of companies. The former are encouraged to invest less in education given the fall in its returns while the latter are encouraged to modify their productive organisation to benefit from the lower costs of qualified labour.

According to the theory of job matching (Jovanovic, 1979), downgrading is a short run phenomenon. In fact, the possibility of a bad matching between employers and job applicants are supposed result from the lack of information by the agents ${ }^{4}$ and the cost to acquire this information ${ }^{5}$. According to this theory, situations of downgrading constitute for the individuals, errors made during the search for a job. The downgraded individuals will be incited to leave their jobs for one better adapted to their abilities, the situation of downgrading is temporary. On the other hand, situations of "under-education", are considered as durable since, if the demand for graduates is higher than their supply, an undereducated worker can be incited to remain in the company since this situation is financially favourable for him. The company can decide to keep an undereducated employee on the one hand, because it saves the costs of searching for and recruiting a new employee and on the other hand, because the employee can gradually compensate for his insufficient training through the acquisition of experience and know-how.

\footnotetext{
${ }^{3}$ The three approaches are respectively classified into the objective or statistical approach, subjective approach and the normative approach.

${ }^{4}$ This information concern the abilities of individuals and the characteristics of the jobs.

${ }^{5}$ For example, the costs of interviews and job search.

${ }^{6}$ Outclassing refers to a situation in which the level of initial training of an individual is less than the level normally required for the job occupied.
} 
Contrary to the theory of the human capital, signalling models which are based on the hypothesis of information asymmetry of the agents on the job market go from the fact that training does not increase the productivity of workers, it only reveals it. Individuals acquire diplomas which are an indicator or signal to the entrepreneur of their abilities in production (Spence, 1973). The selection of competences by diploma makes it possible to assign the same job to similar individuals and the hierarchy of wages is copied from that of "potential" competences (ability to adapt or to be trained for the job) or revealed abilities. The use of the diploma as criterion of matching is based on the hypothesis that the cost of acquisition of a diploma is lower when the potential of the individual is high. An exogenous reduction in such a cost of acquisition can thus blur the signal associated with the diploma and generate a phenomenon of devaluation of school titles rather than lead to downgrading in its strict sense (Nauze-Fichet and Tomasini, 2002; Kamionka and Vu Ngoc, 2016).

The model of "job competition" developed by Thurow (1975) which is in - line with the downgrading approach to wages questions the economic mechanisms at the origin of inequalities in incomes. Unlike the classical analysis according which wages are an adjustment variable between supply and demand that limits the dispersion of incomes, once the various factors of the heterogeneity of individual labour productivity are taken into account, Thurow holds that this statistics has problems in identifying groups of individuals whose wages are really homogeneous. In fact, from the labour supply approach, individuals are differentiated not by their productivity but by the necessary training cost to occupy a given job. This cost is a function of the background characteristics of the individual i.e. inter alia his internal abilities, his level of education and experience. From the labour demand approach, during recruitment, jobs are first classified on a hierarchical grid based on the qualifications which correspond to the productivity differentials of the jobs and the predefined levels of remunerations. Wages can therefore not constitute an adjustment variable between the supply and demand for a job.

Thurow's job competition model is based on the idea that professional abilities must be transmitted in a more or less formal manner within the framework of the job ("on-the-job training"). Part of the abilities for a job is thus acquired by occupying this job. Thus, labour productivity is a characteristic attached to a given employment and not to the person who occupies this job.

The model of job competition can be used to explain the inequality of wages between individuals with relatively homogeneous characteristics. In fact, each job is a training opportunity and the candidates who postulate form a labour queue having at its head the individuals with the highest certificates. The employers then choose those they believe have the lowest costs of training on the basis of the information they have on their initial training level (diploma). The choice of the employer can be related to chance since two individuals with identical characteristics can be proposed jobs with different qualifications, wages and professional training opportunities. Fondeur (1999) holds that during periods of shortage of qualified jobs, such a vision of the operation of the job market is likely to explain the development of situations of downgrading. For a given level of certificates and given a queue corresponding to an employment, individuals are brought to choose between remaining unemployed and moving to a different queue i.e. to postulate for less qualified jobs. This behaviour does not make it possible to identify an "absolute" adequacy between initial training and qualification for a job given the increasing number of certificates and the relative positions occupied by the workers.

\section{2 - The downgrading of certificates as an irreversible phenomenon}

The function of certification of the educational system appears in the economic literature at the beginning of the seventies with the screening theory of Arrow (1973) going from hypotheses advanced by sociologists (Berg, 1970). Except in the case of transparency of the job market, this theory which concerns only paid jobs remains within the framework of the orthodox hypothesis of competitive markets. In fact, firms have preliminary information (which may not be exact) on the productive abilities of the candidates for a job. This information is provided by the certificate which is used mainly as an imperfect measure of productive abilities rather than proof of acquired competences (Arrow, 1973). Besides Vinokur (1995) holds that schooling is not a "block box", but an "empty box" which is limited to the certification of a hierarchy of abilities that it does not modify. The diploma is thus acquired by an individual to reveal his relative aptitudes. However, an increase in the number of graduates or a reduction in the cost of acquisition of diplomas leads to the acquisition of increasingly higher diplomas to reveal better relative performances. This mechanism inevitably leads to a downgrading of the diplomas, especially when the demand for diplomas does not grow with the number of graduates.

Suppose there exist three socio-professional categories A, B and C with a decreasing level of qualification and three diplomas 1, 2 and 3, diploma 1 being the highest. Under the hypothesis of a perfect screening, the job market must be able to absorb the active population of graduates 1,2 and 3 respectively with the socio-professional categories A, B and C. 
However, based on Arrow's model, if there exists a surplus of potential workers holders of diploma 1, these workers will logically be relegated to the less qualified category B. Depending on the number of graduates, category C could absorb diplomas 1 and 2. In this case, diploma 1 is downgraded to the level of diplomas 2 or 3 and diploma 2 downgraded to the level of diploma 3. Given the low level of demand and the fact that the holders of diploma 3 may not find a job, individuals have to acquire increasingly higher diplomas to avoid relegation and unemployment. Relegation is thus a hysteresis effect in the downgrading of graduates which is an irreversible phenomenon according to screening and signal theories (Lemistre, 2003).

\section{2- Data and descriptive statistics}

Due to the lack of a database relating to a sample of graduates followed on a chronological basis, we cannot consider an analysis based on an inter-temporal comparison to better measure over-education. The Fourth Cameroon Household Survey (ECAM 4) carried out in 2014 seems to provide reliable information on employees, although it is true that employees are a minority relative to the non-wage earners on the one hand and the unemployed on the other hand. This survey reveals that $26,11 \%$ of employees are public and private sector workers, as against $73,89 \%$ who are selfemployed $^{7}$. The distribution of wage earners following their highest certificates shows that $20,47 \%$ are workers without a certificate, 34,78\% are holders of CEP/FSLC, 17,48\% have a BEPC/CAP/GCEOL, 5,33\% have a PROBATOIRE/BP, 10,28\% have a BACCALAUREAT/GCEAL/BEP, 2,54\% have an HND/BTS/DUT/DEUG, 5,03\% have a bachelors, $3,30 \%$ have a MAÎTRISE/DEA and $0,79 \%$ have a DOCTORAT/PHD.

Table 1: Average duration of education of wage earners according to the highest certificate and the socio-professional category

\begin{tabular}{|l|c|}
\hline Variables & Average \\
\hline Certificate & $2,681(0,071)$ \\
\hline Without diploma & $7,428(0,033)$ \\
\hline CEP/FSLC & $10,515(0,017)$ \\
\hline BEPC/CAP/GCEOL & $12,010(0,006)$ \\
\hline PROBATOIRE/BP & $13,038(0,025)$ \\
\hline BACC/GCEAL/BEP & $15,015(0,010)$ \\
\hline BTS/DUT/DEUG & $16(0,001)$ \\
\hline BACHELORS & $19,639(0,114)$ \\
\hline MAÎTRISE/DEA & $21(0,001)$ \\
\hline DOCTORATE/PHD & \\
\hline Socio-professional category & $17,130(0,031)$ \\
\hline Senior staff & $13,338(0,494)$ \\
\hline Management staff & $12,408(0,116)$ \\
\hline Junior staff/Supervisor & $9,283(0,097)$ \\
\hline Skilled worker/employee & $7,441(0,115)$ \\
\hline Employee/Semi-skilled worker & $5,981(0,098)$ \\
\hline Labourer & $6,914(0,229)$ \\
\hline Remunerated apprentice/Intern & \\
\hline
\end{tabular}

The standard deviations are in brackets

Source: ECAM 4, INS, Cameroun, 2014.

Table 1 shows that the average duration of training increases not only with the diplomas but also with the socioprofessional categories. If this result is obvious and logical for certificate holders, it seems to reveal heterogeneity in the duration of training in the socio-professional categories as shown by the relatively high standard deviations. This heterogeneity shows that in the same category, there are different levels of training or education.

\footnotetext{
${ }^{7}$ Non-salaried workers can be classified into business owners, self-employed, non-salaried apprentices and interns, and house-helps.
} 
Table 2: Distribution of wage-earners (in \%) by socio-professional category according to the highest certificate

\begin{tabular}{|l|l|l|l|l|l|l|l|l|}
\hline & C. S. & P.D. & C. M. & E/O-Q & E/O-SQ & MAN & STA-APP & TOTAL \\
\hline S.D. & 0,30 & 3,52 & 1,73 & 11,18 & 25,52 & 40,64 & 34,32 & 20,47 \\
\hline CEP/FSLC & 1,51 & 12,94 & 12,27 & 36,51 & 45,42 & 45,68 & 42,01 & 34,78 \\
\hline BEPC/CAP & 3,04 & 12,94 & 21,87 & 27,54 & 17,52 & 9,60 & 10,06 & 17,48 \\
\hline PROBATOIRE & 1,83 & 7,06 & 11,60 & 7,33 & 4,48 & 1,36 & 3,55 & 5,34 \\
\hline BACC/GCEAL & 11,25 & 21,18 & 27,47 & 12,24 & 5,33 & 2,32 & 5,03 & 10,27 \\
\hline BTS/DUT/DEUG & 3,65 & 8,23 & 10,67 & 1,71 & 0,29 & 0,16 & 1,18 & 2,54 \\
\hline LICENCE & 33,13 & 12,94 & 10,53 & 2,63 & 1,24 & 0,24 & 2,96 & 5,03 \\
\hline MAÎTRISE/DEA & 34,65 & 16,48 & 3,60 & 0,86 & 0,20 & 0,00 & 0,89 & 3,30 \\
\hline DOCTORAT & 10,64 & 4,71 & 0,26 & 0,00 & 0,00 & 0,00 & 0,00 & 0,79 \\
\hline
\end{tabular}

C.S. $=$ Senior staff, P.D. = Management staff, C.M. = Junior Staff,

E/O-Q = Employee or Skilled worker, E/O-SQ = Employee or Semi-skilled worker,

MAN = Labourer, STA-APP $=$ Intern or paid apprentice.

Source: ECAM 4, INS, Cameroun, 2014.

From table 2 which shows the distribution of wage-earners by socio-professional category according to the highest diploma, we can see that the number of senior staff increases with the diploma, except for the holders of professional diplomas (BTS/DUT) and PhDs. This can be explained by the fact that the holders of such diplomas are not numerous on the job market. If it is logical to find that the number of semi-skilled workers and labourers decrease with the diploma, we also notice that the holders of higher diplomas (DEA, Maîtrise, Bachelors, BTS/DUT/DEUG) are also found in these categories. A particular category, that of paid apprentices and interns have a rather important number of higher education graduates which in our opinion can be explained by the fact that the majority of trainings are general and the diploma leading to this job is not the highest the employee has. The holders of DEA/Maîtrise and Bachelors are found in the category of semi-skilled workers just as holders of Bachelors and BTS/DUT/DEUG are found in the category of labourers. However, these findings are not synonymous to poor remuneration although it is true that wages vary with socio-professional category.

The self-evaluation of the worker through which the worker himself specifies the necessary training to perform the function enables us to draw tables 4 and 5 (in the appendix) giving the proportions of wage-earners by diploma and socio-professional category according to their qualification relative to the requirements of employment. We can note that the employees for whom the qualifications required are necessary are mainly for diplomas as well as the socioprofessional categories. However, those whose qualifications are not necessary are in a proportion far from negligible. The latter not only includes the over-educated, but also the under-educated.

\section{3- Econometric Model}

The objective of this study being to measure the returns to education through the adequacy between the diplomas possessed and job occupied, we retain an econometric model aimed at rendering over-education endogenous and integrating the selection bias of Heckman (1979).

The authors who consider that a worker is over-educated when it is exogenous in wage determination use a returns function of the Mincer (1974) type:

$Y=\alpha_{0}+\alpha_{1 k} X_{k i}+\alpha_{2} P_{i}+\varepsilon_{i}$

where $Y$ is the wage of the employee, $\mathrm{X}$ a linear vector of exogenous characteristics (diploma, sex, age,..), $\alpha_{1 k}$ the column vector of the coefficients to be estimated, $\alpha_{2}$ the returns of over-education and $\varepsilon_{i}$ the residuals.

Given that it is not probable that over-educated individuals are selected in a random manner (Dolton and Silles, 2003), the wages of certain individuals can, independently of the employment-qualification situation, be lower. The existence of a strong non-observable individual heterogeneity in the incidence of over-education leads us following the example of Guironnet (2005) to consider a method with treatment effects. In fact, certain characteristics explaining overeducation are inherent in those affecting remuneration, which renders them endogenous. We follow the two stage approach developed by Barnow et al., (1981) and used by Guironnet (2005):

In the first stage, we determine the individual probabilities of over-education using a probit model: 
$P=\quad$ with $P^{*}=\not w+\mu$

0 si $P^{*} \leq 0$

Where $P_{i}$ is the observed result of the downgrading, $P_{i}^{*}$ a latent variable explaining downgrading, $w$ avector of instruments of the individual characteristics having an effect on downgrading. It is supposed that the error terms $\varepsilon$ and $\mu$ follow a bivariate distribution with zero mean and respective variances, $\sigma_{\varepsilon}^{2}, \sigma_{\mu}^{2}$ and covariance $\sigma_{\varepsilon \mu}$. In this model, we use the $\hat{\gamma}$ coefficients estimated to build the conditional estimated means of $\mu$.

In the second stage, the equation (1) is estimated by introducing a correction term for selection bias:

$Y=\alpha X+\lambda P+\beta \hat{\chi}+\mu(3)$

Where $\alpha, \lambda$, and $\beta$ are the parameters estimated by ordinary least squares, $\hat{\chi}$ is the estimated conditional mean of the error term.

In equation (2), if $P=1$ that is equivalent to the event $-\gamma w<\mu$. By supposing that $\sigma_{\mu}^{2}=1, \mu$ follows a standard normal distribution independent of $X$. We thus obtain:

$$
\begin{aligned}
& E\left[\mu \mid X, P^{*}>0\right]=E[\mu \mid X, \mu>-\gamma w]=-\frac{\varphi(\gamma w)}{\phi(\gamma w)} \\
& E\left[\mu \mid X, P^{*} \leq 0\right]=E[\mu \mid X, \mu \leq-\not w]=\frac{\varphi(\gamma w)}{1-\phi(\gamma w)}
\end{aligned}
$$

where $\varphi$ and $\phi$ are respectively the density function and cumulative distribution of the standard normal distribution. We thus have:

$$
\begin{aligned}
E[\mu \mid X, P] & =P \times E[\mu \mid X, P=1]+(1-P) \times E[\mu \mid X, P=0] \\
= & -P \times \frac{\varphi(\mathcal{w})}{1-\phi(\mathcal{w})}+(1-P) \times \frac{\varphi(\mathcal{w})}{\phi(\mathcal{w})}=\frac{\varphi(\phi-1)}{\phi(1-\phi)}=\chi
\end{aligned}
$$

This yields:

$$
E[Y \mid X, P]=\alpha X+\lambda P+\beta \chi \text { with } \beta=\sigma_{\varepsilon \mu}
$$

Thus, if $\sigma_{\varepsilon \mu}<0$, the unobserved characteristics which positively affect the probability of being over-educated have a positive effect on the outcome variable and the ignorance of the selection bias tends to over-estimate the effect of overeducation; if $\sigma_{\varepsilon \mu} \geq 0$, not taking into account selection bias tends to underestimate the incidence of over-education.

\section{4- Results}

The growth of enrolment in state universities and secondary schools combined with the high success rates lead to an increase in the number of graduates from year to year. This quantitative increase in the number of graduates naturally leads to a questioning of the ability of the economic system to absorb such an increase in the number of graduates under conditions in conformity with the expectations of these graduates. Tables 4 and 5 in the appendix show that for certain individuals, the most important thing is to find a job, even if this job is not in line with the qualifications of the graduate. This shows that there is a risk of degradation of diplomas which can be extended to the hierarchy of all diplomas given that due to the lack of good jobs, the surplus of diplomas of higher level will seek lower level jobs. However, this degradation can be compensated by a wages policy which goes beyond the internal function of quality control in the production lines of companies. The estimation of the model presented above gives us the following results: 
Table 3: Function of returns of the workers

\begin{tabular}{|l|c|c|}
\hline \multirow{2}{*}{ Variables } & \multicolumn{2}{|c|}{ Estimated parameters } \\
\cline { 2 - 3 } & Simple estimate (MCO) & Model estimate \\
\hline Constant & $7,885 * * *(0,128)$ & $7,784 * * *(0,129)$ \\
\hline Sex (Reference: female) & - & - \\
\hline Male & $0,218^{* * *}(0,025)$ & $0,217 * * *(0,025)$ \\
\hline Age & $0,077 * * *(0,006)$ & $0,076 * * *(0,006)$ \\
\hline Square of age & $-0,0008 * * *(0,00009)$ & $-0,0008 * * *(0,00009)$ \\
\hline Experience & $0,042 * * *(0,003)$ & $0,037 * * *(0,003)$ \\
\hline Square of experience & $-0,0005 * * *(0,00009)$ & $-0,0005 * * *(0,00009)$ \\
\hline Branch of industry (ref.: public) & - & - \\
\hline Private sector & $0,042 * * *(0,003)$ & $0,039 * * *(0,026)$ \\
\hline Residence (ref.: Rural) & - & - \\
\hline Urban residence & $0,395 * * *(0,034)$ & $0,388 * * *(0,034)$ \\
\hline Semi-urban residence & $0,305 * * *(0,038)$ & $0,291 * * *(0,038)$ \\
\hline $\begin{array}{l}\text { Branche of activity (ref.: } \\
\text { primary) }\end{array}$ & - & - \\
\hline Secondary & $0,492 * * *(0,046)$ & $0,482 * * *(0,046)$ \\
\hline Tertiary sector & $0,334 * * *(0,042)$ & $0,330 * * *(0,042)$ \\
\hline Diplomas (ref.: no diploma) & - & - \\
\hline CEP/FSLC & $0,340 * * *(0,029)$ & $0,247 * * *(0,034)$ \\
\hline BEPC/CAP/GCEOL & $0,670 * * *(0,038)$ & $0,517 * * *(0,047)$ \\
\hline PROBATOIRE/BP & $0,891 * * *(0,057)$ & $0,771 * * *(0,061)$ \\
\hline BACC/GCEAL/BEP & $0,983 * * *(0,046)$ & $0,854 * * *(0,051)$ \\
\hline DISUP & $1,415 * * *(0,045)$ & $1,320 * * *(0,048)$ \\
\hline $\begin{array}{l}\text { Education (ref.: years of } \\
\text { education required) }\end{array}$ & - & - \\
\hline Over-education & $-0,373 * * *(0,028)$ & $-0,386(0,041)$ \\
\hline Under-education & $0,073(0,037)$ & $0,047(0,045)$ \\
\hline Adjusted R2 & 0,51 & - \\
\hline & - & $0,076(0,015)$ \\
\hline Rho & 5023 & 5023 \\
\hline Number of observations & & \\
\hline
\end{tabular}

The standard deviations are in brackets

$*$ significant at $10 \%, * *$ significant at $5 \%, * * *$ significant at $1 \%$

Source: ECAM 4, INS, Cameroun, 2014.

Within the framework of the measurement of the effects of over-education on wages, the literature highlights the returns of the years more than the necessary level (Hartog, 2000). In developing countries and Cameroon in particular, obtaining a job passes through several channels leading to the occupation of certain jobs by individuals whose qualifications are higher than the necessary level. The table above describes the effects of over-education, undereducation and various variables on wages.

Beyond the screening role which the diploma plays when it comes to entry into the job market, it appears that their effects on wages are positive and increasing with the level of the diploma. Higher education graduates (DISUP) thus have the highest returns and CEP/FSLC holders the lowest. However, it is important to note that the taking into account of selection bias induced by unemployed graduates decreases the returns of diplomas considerably. The returns of higher education diplomas thus falls from 1,415 to 1,32 . This result shows that education is an investment in capital whose return on investment (wages) is conditioned by obtaining a job. In fact, as highlighted by Blache and Prokovas (2019), the educational level is not always enough to protect young people from the difficulties of insertion.

The other variables like age, experience, branch of industry, area of residence and branch of activity have a positive effect on wages. The returns of place of residence (semi-urban and urban) are high and this is justified by the fact that jobs are mainly found in the cities. The same applies to the branch of activity where employee jobs lie more in the secondary industries and tertiary sector. 
In our two estimations and considering that the public sector is less competitive given that the levels of entrance exams remain traditional, we focus on the private sector. This sector has positive but rather low returns. We can thus confirm the hypothesis put forward by human capital theory according to which the private sector is rather flexible in the attribution of wages in conformity with the educational level of the employee whose selection at the time of recruitment can possibly be of better quality.

The correlation between the returns function and the probit explaining under-education and downgrading shows that the omission of selection bias is at the origin of the over-estimation of the incidence of over-education and undereducation.

The penalty of over-education of an individual given by the correct term to which one adds the effect of downgrading leads to a reduction of about $31,1 \%$ whereas under-education results in an increase of $12,2 \%$. The high reduction corresponding to downgrading is due to the in imbalance between supply and demand of graduates induced by the quest of higher diplomas by Cameroonian youth caused by job scarcity.

\section{Conclusion}

Demographic pressure in Africa and Cameroon in particular is accompanied by an increase in enrolment not only in the primary and secondary education, but also in universities and professional schools. The logical consequence of this increasing enrolment is an increase in the number of graduates on the job market; leading to an increasing imbalance between the supply and demand of graduates (supply is largely higher than demand). However, some graduates manage to develop their abilities on the job market but in the majority of the cases, the necessary correspondence between the diploma and the job is not established. We thus find 43,18\% of over-educated, $21,87 \%$ of under-educated and $34,95 \%$ of employees whose required years of schooling corresponds to the job. These statistics, especially the number of overeducated represents a "quantitative" degradation of diplomas which is distinct from a qualitative "depreciation". Given that this downgrading can be compensated by returns, we estimate the effect of the variables like the diploma, overeducation and under-education on wages. This reveals that the returns of education increase with the diploma. However, the over-education of an individual decreases the returns of education by about $31,1 \%$ while under-education involves an increase of $12,2 \%$.

If it is true that the poor economic conditions can partially explain such an imbalance, for example the penalty on the over-educated, there exist other major reasons that explain the situation of under-education, particularly its benefits. Individuals in order to avoid unemployment have to seek increasingly higher diplomas and given the imbalance between the supply and demand for diplomas, this results in a fall in the relative position in the hierarchy of diplomas since the surplus of graduates at the highest level is carried to lower levels due to the lack of suitable jobs. Individuals with the least certificates are then most vulnerable. Thus, the signalling role of the diploma is reduced with the increasingly supply of diplomas.

\section{References}

Aliaga, C. \& Lê, J. (2016), "L'insertion des jeunes sur le marché du travail: l'emploi est majoritaire chez les plus diplômés, l'inactivité domine chez les non-diplômés", INSEE, France, portrait social, pp. 43-57.

Barnow B., Cain, G. \& Goldberger, A. (1981), "Issues in the analysis of selectivity bias", Evaluation Studies Review Annual, 5.

Baudelot, C. \& Glaude, M. (1989), "Les diplômes se dévaluent-ils en se mulptipliant", Economie et Statistique, 225, PP. 3-15.

Berg, I. (1970), Education and Jobs, the Great Training Robbery, Penguin Education, 194P.

Blache, G. \& Prokovas, N. (2019), "L'accompagnement intensif des jeunes chômeurs: quels effets sur leur insertion ?", Formation emploi, 148, PP. 25-46.

Boisson-Cohen, M., Garner, H. \& Zamora, P. (2017), L'insertion professionnelle des jeunes, DARES _ $\quad$ France Stratégie.

Caliendo, M. \& Schmidl, R. (2016), "Youth unemployment and active labor market policies in Europe", IZA, Journal of Labor Policy, vol. 5, issue 1, pp. 1-30.

Dolton, P. \& Vignoles, A. (2000), "Incidences and effects of overeducation in the UK graduate labour market", Economics of Education Review, 19(2), PP. 179-198.

\footnotetext{
${ }^{8}$ The correlation coefficient 0,075 enables us to obtain $0,075-0,386=-0,311$ (i.e. $31,1 \%$ ) for over-education and $0,075+$ $0,047=0,122$ (i.e. $12,2 \%$ ) for under-education.
} 
Dolton, P. \& Silles, M. (2003), "The determinant and consequences of graduate overeducation", Working Paper, Lasmas Conférence.

Duncan, G. \& Hoffman, S. D. (1981), "The incidence and wage effects of over-education", Economics of Education Review, 1(1), PP. 75-86.

Fondeur, Y. (1999), "Le déclassement à l'embauche", étude réalisée pour le Commissariat Général du Plan, IRES.

Freeman, R. B. (1976), The Overeducated American, New York, NY: Academic Press.

Gamel, C. (2000), "Le diplôme, un «signal » en voie de dépréciation? le modèle de Spence réexaminé", Revue d'Economie Politique, 110(1), PP. 53-84.

Giret, J-F., Nauze-Fichet, E. \& Tomasini, M. (2006), "Le déclassement des jeunes sur le marché du travail", Données sociales - La société française, édition 2006, pp. 307-314.

Groot, W. \& Masssen Van Den Brink, H. (2000), "Overeducation in the labor market: A meta analysis", Economics of Education Review, 19(2), PP. 149-158.

Guironnet, J.-P. (2005), "La suréducation en France: Vers une dévalorisation des diplômes du supérieur ?", Communication présentée au «SESAME - XV ${ }^{\text {èmes }}$ Journées», Rennes, 26 et 27 septembre.

Hartog, J. (1999), "Sur-éducation et sous-éducation dans une perspective de formation professionnelle", Revue Européenne Formation Professionnelle, 16, PP. 53-58.

Hartog, J. (2000), "Overeducation and earnings: where are we, where should we go ? ", Economics of Education Review, 19(2), PP. 131-148.

Heckman, J. J. (1979), "Sample selection bias as a specification error", Econometrica, 47(1), PP. 153-161.

Jovanovic, B. (1979), "Job matching and the theory of turnover", Journal of Political Economy, 87(5), PP. 972-990.

Kamionka, T. \& Vu Ngoc, X. (2016), "Insertion des jeunes sur le marché du travail, diplôme et quartier d'origine: une modélisation dynamique", Revue économique, vol. 67, n 3, pp. 463-494.

Lemistre, P. (2003), "Dévalorisation des diplômes et accès au premier emploi", Revue d'Economie Politique, 1.

Manga Engama, E. (2007), "Education et salaire au Cameroun: quelle relation?", Revue Internationale de Sciences Humaines et Sociales, L'Harmattan, 2(2), PP. 13-41.

Mincer, J. (1974), "Schooling, experience and earnings", National Bureau of Economic Research, New York.

Nauze-Fichet, E. \& Tomasini, M. (2002), "Diplôme et insertion sur le marché du travail: approches socioprofessionnelles et salariale du déclassement", Economie etStatistique, n 354, pp. 21-43.

Rubb, S. (2003), "Overeducation: a short or long run phenomenon for individuals", Economics of Education Review, 22, PP. 389-394.

Sicherman, N. (1991), "Overeducation in the labor market", Journal of Labour Economics, 9(2), PP. 101-122.

Sloane, P. J., Battu, H. \& Seaman, P. T. (1999), "Overeducation, Undereducation and the British Labour Market", Applied Economics, $\mathrm{n}^{\circ} 31$, pp. 1437-1453.

Spence, M. (1973), "Job Market Signalling", Quarterly Journal of Economics, vol. 87, pp. 353-374.

Thurow, L. C. (1975), Generating Inequality, Basic Books, New York.

Verhaest, D. \& Omey, E. (2004), "What determines measured overeducation ?", Ghent University Working Paper.

Vinokur, A. (1995), "Réflexions sur l'économie du diplôme", Formation-emploi, 52, PP. 151-184.

\section{Appendices}

Table 4: Proportion of wage-earners by diploma according to their qualification relative to the requirements of the job

\begin{tabular}{|l|c|c|}
\hline Diploma & \multicolumn{2}{|c|}{ Qualification required } \\
\hline Without diploma & Yes & Not \\
\hline Without Diploma & $0,194(0,006)$ & $0,230(0,011)$ \\
\hline CEP/FSLC & $0,341(0,007)$ & $0,368(0,013)$ \\
\hline BEPC/CAP/GCEOL & $0,167(0,006)$ & $0,195(0,010)$ \\
\hline PROBATOIRE/BP & $0,054(0,003)$ & $0,049(0,005)$ \\
\hline BACC/GCEAL/BEP & $0,104(0,004)$ & $0,098(0,008)$ \\
\hline BTS/DUT/DEUG & $0,029(0,002)$ & $0,014(0,003)$ \\
\hline BACHELORS & $0,056(0,003)$ & $0,032(0,004)$ \\
\hline MAÎTRISE/DEA & $0,041(0,003)$ & $0,009(0,002)$ \\
\hline DOCTORATE/PhD. & $0,010(0,001)$ & $0,0007(0,0007)$ \\
\hline
\end{tabular}

The standard deviations are in brackets

Source: ECAM 4, INS, Cameroun, 2014. 
Table 5: Proportion of wage-earners by socio-professional category according to their qualification relative to the requirements of the job

\begin{tabular}{|l|c|c|}
\hline \multirow{2}{*}{ Socioprofessional categories } & Yes & Qualification required \\
\cline { 2 - 3 } & $0,018(0,002)$ & $0,011(0,002)$ \\
\hline Management staff & $0,079(0,004)$ & $0,015(0,003)$ \\
\hline Senior Staff & $0,171(0,006)$ & $0,062(0,006)$ \\
\hline Junior staff & $0,314(0,007)$ & $0,142(0,009)$ \\
\hline Skilled worker/ employee & $0,186(0,006)$ & $0,249(0,011)$ \\
\hline Semi-skilled worker & $0,176(0,006)$ & $0,422(0,013)$ \\
\hline Labourer & $0,053(0,003)$ & $0,096(0,008)$ \\
\hline Paid apprentice/ Intern & & \\
\hline
\end{tabular}

The standard deviations are in brackets

Source: ECAM 4, INS, Cameroun, 2014. 